\title{
Effect of Chemical, Organic and Bio-fertilizers on the Availability of some Nutrients
} in Grafted Orange Seedlings

\section{Ayad Hani Ismail Al-Allaf and Nameer Najib Fadel Hadeed}

Department of Horticulture and Garden Engineering, College of Agriculture and Forestry, Mosul University, Iraq

Received: 10 Sept. 2019 / Accepted 30 Oct. 2019 / Publication date: 10 June 2020

\begin{abstract}
The experiment aimed to show the demonstrate of two spring grafting dates $\left(2^{\text {nd }}\right.$ and $17^{\text {th }}$ April $)$ and fertilization of local oranges seedlings grafted on bitter orange rootstock to compound fertilizer (NPK) at $30 \mathrm{~g} /$ seedling, organic liquid fertilizer "Nutrigreen" at $6 \mathrm{ml} / \mathrm{L}$ and using three types of biofertilizers such as Biogen at 3 and $6 \mathrm{~g} /$ seedling, Potasiomag at 5 and $10 \mathrm{~g} /$ seedling and Fulzyme at 1 $\mathrm{g} /$ seedling as a nutrient elements. The experiment was designed using of the complete randomized block design (RCBD) with three replicates and five seedlings per experimental unit. Averages were compared using Dunkin test at 5\% level.

The results showed that there were significant differences between the dates of grafting with nutrient elements, while treatment of NPK compound fertilizer was superior to the treatment of 30 $\mathrm{g} /$ seedling comparison with the nutrient elements of nitrogen and phosphorus in the soil. In addition, the organic and bio liquid fertilizers were significantly superior to the comparison treatment with the nutrient elements of nitrogen, potassium and phosphorus in the soil.
\end{abstract}

Keywords: Grafting dates, fertilization, orange, NPK, bio-fertilizers, nutrient elements.

\section{Introduction}

Shield grafting (T-grafting) is the common method of propagating commercial citrus species grafted on the seeds rootstocks of citrus in Iraq, where the desired varieties are grafted on the seeds and vegetation rootstocks of some citrus species and species at different dates either in the spring during (March and April) or in the autumn (September and October) (Chaudhary, 2000). The date of grafting affects the increase in the success process of grafting, as the timely procedure helps to increase the success rate of developing grafts, which is reflected in the effect of vegetative and root growth and thus increase the yield of the tree (Hartmann et al., 2011).

The weak and slow growth of conjunctiva buds in the grafting process is a major impediments to the grafted citrus seedlings in the nurseries, and this can be reduced by fertilizing the grafted seedlings with the essential elements of their growth as sufficient amounts of large elements, especially nitrogen, phosphorus and potassium, are necessary for the growth of citrus plants (Liu, 2010). Also, organic fertilizers of various types, including liquid form are an important and essential source of the macro and micro elements needed by the plant. The Nutrigreen fertilizer is considered one of the most important liquid organic fertilizers as it contains organic nitrogen that turns into mineral nitrogen by the microorganisms present in the soil which is absorbed by the seedlings as it increases the building of chlorophyll and organic carbon that enters the synthesis of all organic compounds and constitutes $50 \%$ of the dry weight of most plants. The fertilizer also contains organic matter, which is of great importance in improving the physical and biological properties of the soil by dismantling heavy soil granules and improving their ventilation as well as increased soil retention ability (Hassan et al., 2010).

On the other hand, bio-fertilizers are considered to be environmentally friendly fertilizers, which are fertilizers containing microorganisms that are able to supply plants with the necessary nutrients from natural sources, which reduces dependence on various chemical fertilizers, which leads to reducing environmental pollution and production costs and increasing the yield in terms of quality and quantity (Scialabba, 2002). Bio-fertilizers also supply plants with their nutritional needs by providing nutrients in a ready way in the cultivated soil, such as nitrogen, which is installed by bacteria and phosphorus, which prepares the mycorrhizal fungi so that the roots of the seedlings can

Corresponding Author: Ayad Hani Ismail Al-Allaf, Department of Horticulture and Garden Engineering, College of Agriculture and Forestry, Mosul University, Iraq 
be absorbed and taken advantage of, in addition to the fact that they by reducing the level of soil $\mathrm{pH}$, which increases the readiness of the micronutrients needed by the plant, in addition to supplying them with stimulants for plant growth, such as hormones and growth regulators such as oxins, gibberelins, and cytokinins (Shaimaa and Massoud, 2017).

The target of this study was elucidating the effect of grafting date and chemical, organic and bio-fertilizers on the availability of some nutrients in grafted orange seedlings.

\section{Materials and Methods}

The study was conducted in the wooden canopy of the Department of Horticulture and Garden Engineering / College of Agriculture and Forestry, Mosul University during the growth season 2018 with the aim of showing two dates for spring grafting $\left(2^{\text {nd }}\right.$ and $17^{\text {th }}$ April) with local oranges (Citrus sinensis) seedlings grafted on bitter orange (Citrus aurantium) rootstock and the addition of chemical fertilization (NPK) and liquid organic (Nutrigreen) and three types of bio-fertilizers including, Biogen, Potasiomag and Fulzyme in the subsequent growth of grafted seedlings

Seedlings were selected as a two-year-old rootstock (the height was 90-100 cm and the diameter of the main stem in the grafting area was $7-8 \mathrm{~mm}$ ) and planted in plastic containers was $8 \mathrm{~kg}$, height was $30 \mathrm{~cm}$ and diameter was $25 \mathrm{~cm}$ containing soil and animal manure (sheep residues) at a ratio of 1: 3 that was mixed in a homogeneous way. The orange grafts were taken from the same mature year growths and from strong and productive trees from pathological injuries and insects from private gardens in the city of Mosul.

The experiment was designed according to the split-split system in a factorial experiment using the Completely Randomized Block Design (R.C.B.D). Three factors consist of two grafting dates, two concentrations of compound chemical fertilizer, seven concentrations of bio-fertilizers and liquid organic fertilizers. Thus, the number of treatments was 28 treatments with three replicates, so the number of experimental units reached 84 units and by 5 seedlings per treatment in each replicates, thus the number of seedlings used in the experiment 420 seedlings.

T-budding was used in the spring of 2018 with two dates (April $2^{\text {nd }}$ and $17^{\text {th }}$ ) at a height of (15$20 \mathrm{~cm}$ ) above the soil surface level. After bud burst, the grafted seedlings were fertilized with three types of fertilizers: fertilizer with compound fertilizer (20:20:20) NPK, where it was added at $30 \mathrm{~g}$ /seedling for two batches, the first was added by $15 \mathrm{~g}$ on $(21 \mathrm{March})$, while the second batch was added with the same amount on ( $2^{\text {nd }}$ May) and organic fertilization was added through the liquid Nutrigreen fertilizer at a concentration of $6 \mathrm{ml} /$ liter for two batches, the first on (March 26) and the second (May $3^{\text {rd }}$ ), then bio-fertilization was added through by three types of fertilizers including Biogen was added in two concentrations of 3 and $6 \mathrm{~g}$ per seedling, Potasiomag was added in two concentrations of 5 and $10 \mathrm{~g}$ per seedling and Fulzyme was added a concentrations of $1 \mathrm{~g}$ per seedling which was added in one batch on $21^{\text {st }}$ March.

At the end of the study, the following characteristics were measured:

Concentration of mineral elements in soil: The chemical analysis process was conducted in the soil of the grafted seedlings at the end of the season to estimate the following elements:

Nitrogen: It was determined using the Kjeldahl method according to the method adopted by

Bremner and Mulvaney (1982).

Phosphorus: It was determined using Spectrophotometer according to the method described by Page et al. (1982).

Potassium: It was determined using Flame Photometer according to the method described by Jackson (1958).

$\mathrm{pH}$ : The $\mathrm{pH}$ of the soil extract was estimated using a $\mathrm{pH}$-meter (multiline $\mathrm{P} 4$ / set-2) as reported in Page et al. (1982).

\section{Experimental design and statistical Analysis}

The complete randomized block design was adopted for this experiment. The results were analyzed statistically using computer SAS / STAT (2001). Averages were compared using the Duncan test at 5\% level according to Duncan (1955). 


\section{Results}

\section{Nitrogen content in soil}

Data in table (1) showed that, there were no differences significant between the dates of grafting on content of nitrogen in the soil. Untreated seedlings (control) had the highest content of nitrogen in the soil, where it significantly superior to fertilization through treatment NPK at a concentration of $30 \mathrm{~g} /$ seedling, which had the lowest one, while the concentrations of bio-fertilizers and organic fertilizers positively affected this one, as it had the highest significant content of nitrogen in the soil compared to untreated seedlings and that the best concentrations added effect is 6 $\mathrm{g} /$ seedling of Biogen fertilizer, as the treated seedling in this concentration had the highest one and a significant difference from the value in non-treated seedlings, which had the lowest one.

Table 1: Effect of date of grafting and chemical, organic and bio-fertilizers on the nitrogen content "mg/kg" in the soil of grafted orange seedlings.

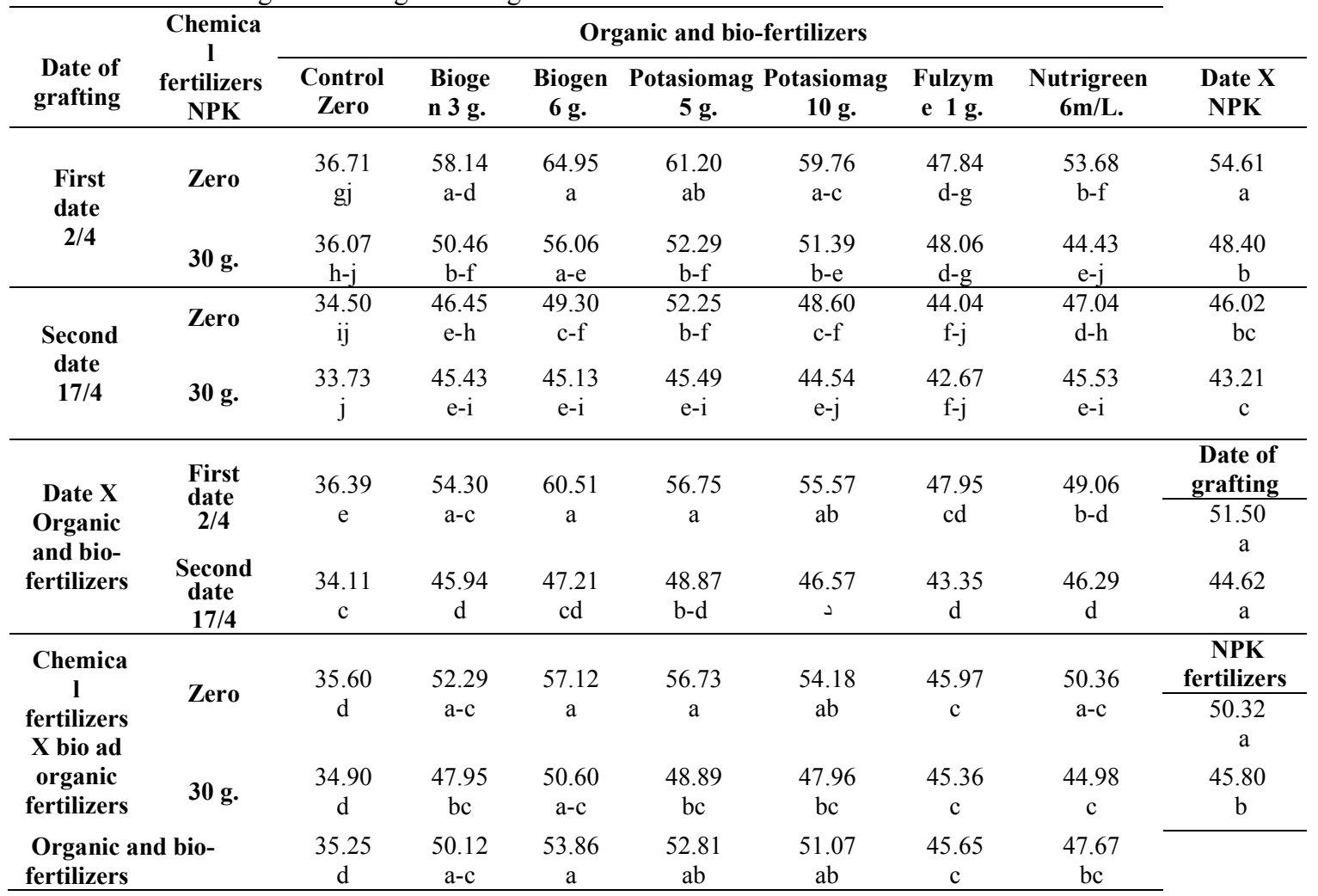

*Mean averages followed by different letters indicate significant differences between them according to Duncan polynomial test at a level of $5 \%$

With regard to the effect of interaction between the dates of grafting and chemical fertilization (NPK), it was obvious that untreated seedlings (control) of NPK fertilizer for grafted seedlings at the first date had a remarkable superiority in increasing this one, and it differed significantly from the other interventions, especially between the concentration of $30 \mathrm{~g}$ of fertilizer NPK for grafted seedlings on the second date, which gave the lowest one.

As for the effect of interaction between the dates of grafting and the organic and bio-fertilizers, it was showed that all treatments of adding these fertilizers during the two grafting dates exceeded the control treatment of nitrogen levels in the soil, where it was observed that the best treatments were when adding the biofertilizer "biogen" fertilizer at a concentration of $6 \mathrm{~g}$ in the first date followed interaction treatment between the addition of Potasiomag fertilizer at a concentration of $5 \mathrm{~g}$ at the same time, while the untreated seedlings (control) treatment for the added fertilizer for grafted seedlings in the two dates gave the lowest of this one. 
With regard to the effect of the interaction between chemical fertilization (NPK) and bio- and organic fertilizers, it was found that the highest significant contents was obtained from untreated seedlings (control) of NPK $+6 \mathrm{~g}$ Biogen fertilizer followed by untreated seedlings (control) of NPK + 5 g Potasiomag fertilizer, while fertilizer NPK + untreated seedlings (control) of bio- and organic fertilizers showed a significant decrease in the nitrogen levels in the soil.

As for the effect of the interaction among the dates of grafting, chemical fertilization (NPK) and bio- and organic fertilizers: it was clear that highest significant contents was obtained from untreated seedlings (control) of NPK $+6 \mathrm{~g}$ Biogen fertilizer at the first date, which had the highest content of nitrogen in the soil in comparison with the other triple interactions, especially among the untreated seedlings (control) of organic and bio-fertilizers + NPK fertilizer concentrations in the two dates, which showed a significant decrease in the nitrogen levels in the soil.

\section{Phosphorus content in soil}

As shown in Table (2), it was showed that the phosphorus content in soil was not significantly affected by different grafting dates, whereas the content of phosphorus in soil decreased significantly by adding NPK fertilizer as the treatment of non-fertilizer (control) was added, while the treatment of $30 \mathrm{~g} /$ seedling recorded the lowest values, and the phosphorus content increased significantly by adding all of these fertilizers compared to the control treatment. The best of these treatments was the treatment of bio-fertilizer "Fulzym" at a concentration of $1 \mathrm{~g} /$ seedling followed by the treatment of adding bio-fertilizer "Potasiomag" at a concentration of $5 \mathrm{~g} /$ seedling, which recorded the highest content of phosphorus, while the control treatment gave the lowest percentage for this one.

Table 2: Effect of date of grafting and chemical, organic and bio-fertilizers on the phosphorus content "mg/kg" in the soil of grafted orange seedlings

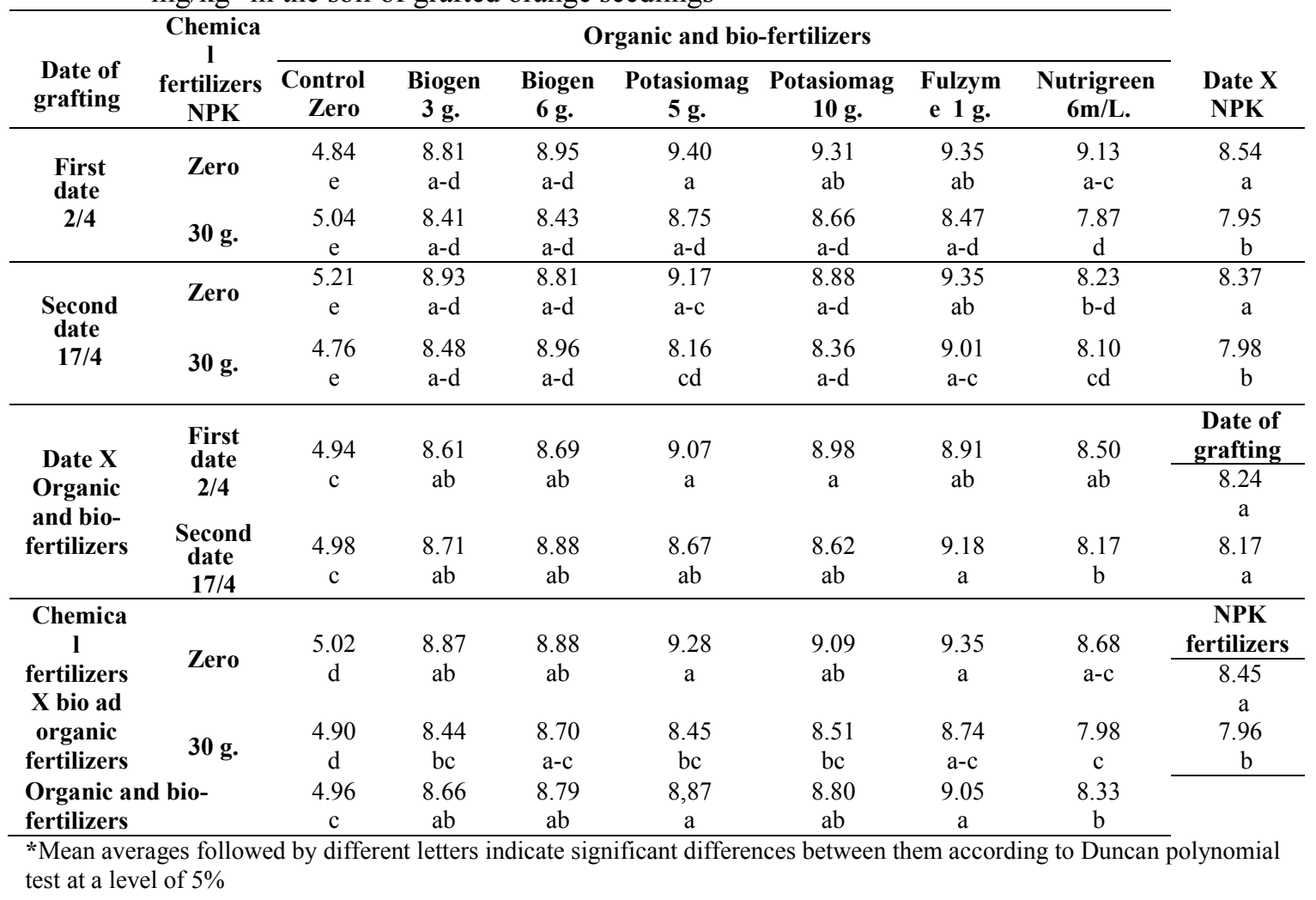

With regard to the effect of interaction between the dates of grafting and chemical fertilization (NPK), it was obvious that the non-application of fertilizer (control) of NPK fertilizer for grafted seedlings at the first and second dates significantly increased as compared to $30 \mathrm{~g}$ NPK at both dates.

As for the effect of interaction between the dates of grafting and the organic and bio-fertilizers, it was showed that the addition of these fertilizers positively affected the increase in the phosphorous 
content of the soil during the two grafting dates, as the treatment of adding fertilizer Fulzym at a concentration of $1 \mathrm{~g}$ for grafted seedlings in the second date gave the highest significant percentage followed by the treatment of adding bio-fertilizer Potasiomag fertilizer at a concentration of 5 and 10 $\mathrm{g}$ for grafted seedlings at the first date, while, less significant content of this one was as a result of control treatment of organic and bio-fertilizers during the first and second grafting dates.

With regard to the effect of the interaction between chemical fertilization (NPK) and organic and bio- fertilizers, it was found that untreated seedlings (control) of NPK $+1 \mathrm{~g}$ concentration of biofertilizer "Fulzyme" was significantly superior to all treatments in soil content of phosphorus, as it gave the highest content followed by the control treatment of NPK fertilizer $+5 \mathrm{~g}$ of fertilizer "Potasiomag", while treatment of NPK fertilizer + control treatment of organic and bio- fertilizers had the lowest values.

As for the effect of the interaction among the dates of grafting, chemical fertilization (NPK) and organic and bio- fertilizers, it was clear that the control treatment of NPK fertilizer $+5 \mathrm{~g}$ of bifertilizer "Potasiomag" for grafted seedlings at the first date gave the highest phosphorous content in the soil, while treatment $30 \mathrm{~g}$ NPK fertilizer + control treatment of organic and bio-fertilizers for grafted seedlings at the second date recorded the lowest of these values.

\section{Potassium content in the soil}

The results indicated in Table (3) showed that there were no significant differences between the dates of grafting on potassium content in the soil. The addition of NPK did not lead to a significant increase in this one, whereas, fertilizer treatments were given to both bio-fertilizer " Potasiomag" in concentrations of 5 and $10 \mathrm{~g}$ and organic fertilizer "Neutergreen" at a concentration of $6 \mathrm{ml} / \mathrm{L}$ had the highest significant value in this one compared to the control treatment, which had the lowest values to this one.

Table 3: Effect of date of grafting and chemical, organic and bio-fertilizers on the potassium content "mg/kg" in the soil of grafted orange seedlings

\begin{tabular}{|c|c|c|c|c|c|c|c|c|c|}
\hline \multirow[b]{2}{*}{$\begin{array}{l}\text { Date of } \\
\text { grafting }\end{array}$} & \multirow{2}{*}{$\begin{array}{c}\text { Chemica } \\
\text { I } \\
\text { fertilizers } \\
\text { NPK }\end{array}$} & \multicolumn{7}{|c|}{ Organic and bio-fertilizers } & \multirow[b]{2}{*}{$\begin{array}{l}\text { Date X } \\
\text { NPK }\end{array}$} \\
\hline & & $\begin{array}{c}\text { Control } \\
\text { Zero }\end{array}$ & $\begin{array}{c}\text { Biogen } \\
3 \text { g. }\end{array}$ & $\begin{array}{c}\text { Biogen } \\
6 \mathrm{~g} .\end{array}$ & $\begin{array}{c}\text { Potasiomag } \\
5 \mathrm{~g} .\end{array}$ & $\begin{array}{c}\text { Potasiomag } \\
10 \mathrm{~g} .\end{array}$ & $\begin{array}{l}\text { Fulzym } \\
\text { e } 1 \mathrm{~g} .\end{array}$ & $\begin{array}{c}\text { Nutrigreen } \\
6 \mathrm{~m} / \mathrm{L}\end{array}$ & \\
\hline \multirow{2}{*}{$\begin{array}{c}\text { First } \\
\text { date } \\
2 / 4\end{array}$} & Zero & $\begin{array}{c}125.97 \\
\text { ef }\end{array}$ & $\begin{array}{c}149.16 \\
a-f\end{array}$ & $\begin{array}{c}173.99 \\
a-c\end{array}$ & $\begin{array}{c}190.04 \\
\mathrm{a}\end{array}$ & $\begin{array}{c}187.85 \\
a b\end{array}$ & $\begin{array}{c}158.49 \\
\text { a-e }\end{array}$ & $\begin{array}{c}181.67 \\
a-c\end{array}$ & $166.74 \mathrm{a}$ \\
\hline & $30 \mathrm{~g}$. & $\begin{array}{c}111.00 \\
\mathrm{f}\end{array}$ & $\begin{array}{c}152.33 \\
\mathrm{a}-\mathrm{e}\end{array}$ & $\begin{array}{c}167.00 \\
a-d\end{array}$ & $\begin{array}{c}172.86 \\
\mathrm{a}-\mathrm{c} \\
\end{array}$ & $\begin{array}{c}170.38 \\
\mathrm{a}-\mathrm{c} \\
\end{array}$ & $\begin{array}{c}160.35 \\
a-e\end{array}$ & $\begin{array}{c}147.13 \\
b-f\end{array}$ & $154.43 \mathrm{a}$ \\
\hline \multirow{2}{*}{$\begin{array}{c}\text { Second } \\
\text { date } \\
17 / 4\end{array}$} & Zero & $\begin{array}{c}127.67 \\
\text { d-f }\end{array}$ & $\begin{array}{c}154.18 \\
\text { a-e }\end{array}$ & $\begin{array}{c}168.22 \\
a-d\end{array}$ & $\begin{array}{c}169.01 \\
a-c\end{array}$ & $\begin{array}{c}172.30 \\
\mathrm{a}-\mathrm{c}\end{array}$ & $\begin{array}{c}148.54 \\
b-f\end{array}$ & $\begin{array}{c}177.43 \\
a-c\end{array}$ & $159.62 \mathrm{a}$ \\
\hline & $30 \mathrm{~g}$. & $\begin{array}{c}149.88 \\
\text { a-e }\end{array}$ & $\begin{array}{c}144.26 \\
c-f\end{array}$ & $\begin{array}{c}154.98 \\
\text { a-e }\end{array}$ & $\begin{array}{c}159.42 \\
\text { a-e }\end{array}$ & $\begin{array}{c}167.91 \\
a-d\end{array}$ & $\begin{array}{c}163.17 \\
\text { a-e }\end{array}$ & $\begin{array}{c}179.53 \\
\text { a-c }\end{array}$ & $195.87 \mathrm{a}$ \\
\hline \multirow{2}{*}{$\begin{array}{c}\text { Date X } \\
\text { Organic } \\
\text { and bio- } \\
\text { fertilizers }\end{array}$} & $\begin{array}{c}\text { First } \\
\text { date } \\
2 / 4\end{array}$ & $\begin{array}{c}118.49 \\
d\end{array}$ & $\begin{array}{c}150.75 \\
\text { bc }\end{array}$ & $\begin{array}{c}170.49 \\
a b\end{array}$ & $\begin{array}{c}181.45 \\
\mathrm{a}\end{array}$ & $\begin{array}{c}179.12 \\
\mathrm{a}\end{array}$ & $\begin{array}{c}159.42 \\
\text { a-c }\end{array}$ & $\begin{array}{c}164.40 \\
a-c\end{array}$ & 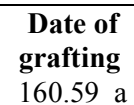 \\
\hline & $\begin{array}{c}\text { Second } \\
\text { date } \\
17 / 4 \\
\end{array}$ & $\begin{array}{c}138.78 \\
\text { cd }\end{array}$ & $\begin{array}{c}149.22 \\
\text { bc }\end{array}$ & $\begin{array}{c}161.61 \\
a-c\end{array}$ & $\begin{array}{c}164.22 \\
a-c\end{array}$ & $\begin{array}{c}170.11 \\
\mathrm{ab}\end{array}$ & $\begin{array}{c}155.85 \\
a-c\end{array}$ & $\begin{array}{c}178.48 \\
\mathrm{a}\end{array}$ & $159.75 \mathrm{a}$ \\
\hline $\begin{array}{c}\text { Chemica } \\
\text { I } \\
\text { fertilizers }\end{array}$ & Zero & $\begin{array}{c}126.82 \\
\mathrm{e}\end{array}$ & $\begin{array}{c}151.67 \\
b-e\end{array}$ & $\begin{array}{c}171.11 \\
\mathrm{a}-\mathrm{c}\end{array}$ & $\begin{array}{c}179.53 \\
a b\end{array}$ & $\begin{array}{c}180.08 \\
\mathrm{a}\end{array}$ & $\begin{array}{c}153.51 \\
a-d\end{array}$ & $\begin{array}{c}179.55 \\
a b\end{array}$ & $\begin{array}{c}\text { NPK } \\
\text { fertilizers } \\
163.18 \mathrm{a}\end{array}$ \\
\hline $\begin{array}{l}X \text { bio ad } \\
\text { organic } \\
\text { fertilizers }\end{array}$ & $30 \mathrm{~g}$. & $\begin{array}{c}130.44 \\
\text { d-e }\end{array}$ & $\begin{array}{c}148.30 \\
\text { c-e }\end{array}$ & $\begin{array}{c}160.99 \\
a-c\end{array}$ & $\begin{array}{c}166.14 \\
\text { a-c }\end{array}$ & $\begin{array}{c}169.15 \\
a-c\end{array}$ & $\begin{array}{c}161.76 \\
a-c\end{array}$ & $\begin{array}{c}163.33 \\
\mathrm{a}-\mathrm{c}\end{array}$ & $157.15 \mathrm{a}$ \\
\hline \multicolumn{2}{|c|}{$\begin{array}{l}\text { Organic and bio- } \\
\text { fertilizers }\end{array}$} & $\begin{array}{c}128.63 \\
\mathrm{c}\end{array}$ & $\begin{array}{c}149.98 \\
\mathrm{~b}\end{array}$ & $\begin{array}{c}166.05 \\
\mathrm{ab}\end{array}$ & $\begin{array}{c}172.83 \\
\mathrm{a}\end{array}$ & $\begin{array}{c}174.61 \\
\mathrm{a}\end{array}$ & $\begin{array}{c}157.63 \\
\mathrm{ab}\end{array}$ & $\begin{array}{c}171.43 \\
\mathrm{a}\end{array}$ & \\
\hline
\end{tabular}


With regard to the effect of interaction between the dates of grafting and chemical fertilization (NPK), it was obvious that no significant difference between seedlings grafting dates and chemical fertilization (NPK) on potassium content in the soil.

As for the effect of interaction between the dates of grafting and the organic and bio-fertilizers, it was showed that the organic and bio-fertilizers treatments with the date of grafting of seedlings had a positive effect on potassium content in the soil. The addition of the bio-fertilizer " Potasiomag" in the 5 and $10 \mathrm{~g}$ concentrations of grafted seedlings at the first date, and the organic fertilizer "Neutrogreen" with a concentration of $6 \mathrm{ml} / 1$ for grafted seedlings on the second date, gave significantly higher values, while the control treatment of these fertilizers for seedlings grafted on the two dates, especially at the first date, they gave the lowest values of this one.

With regard to the effect of the interaction between chemical fertilization (NPK) and organic and bio- fertilizers, it was found that untreated seedlings (control) of NPK fertilizer $+10 \mathrm{~g}$ of biofertilizer "Potasiomag" recorded a remarkable superiority of potassium content in the soil, while the control treatment of NPK + the organic and bio-fertilizers treatments recorded the lowest values of this one.

As for the effect of the interaction among the dates of grafting, chemical fertilization (NPK) and organic and bio- fertilizers, it was clear that the control treatment for both NPK fertilizers and organic and bio-fertilizers for grafted seedlings at the first date recorded the lowest significant value of potassium content in the soil, while the control treatment for each of the NPK $+5 \mathrm{~g}$ fertilizer of the bio-fertilizer "Potassiumage" for grafted seedlings at the same date recorded the highest significant values of this one.

\section{Soil pH}

As shown in Table (4), it was showed that the date of grafting did not significantly affect the soil $\mathrm{pH}$, as there were no significant differences between the date of the first and second grafting on the soil $\mathrm{pH}$, while the control treatment gave the lowest level reached 6.97 compared to the treatment of $30 \mathrm{~g}$ of NPK fertilizer, which gave the highest level at 7.01. The seedlings treated with all concentrations of organic and bio-fertilizers had the lowest levels of soil $\mathrm{pH}$ compared to the control treatment and that the lowest level reached 6.89 when adding the organic fertilizer "Nutrigreen" at a concentration of $6 \mathrm{ml} /$ liter, contrary to what the seedlings gave in the control treatment that gave the highest Significant level of soil $\mathrm{pH}$ was 7.29.

With regard to the effect of interaction between the dates of grafting and chemical fertilization (NPK), it was obvious that the treatment of adding $30 \mathrm{~g}$ of NPK fertilizer to the grafted seedlings at the first date gave a significant advantage in soil $\mathrm{pH}$, while the control treatment of NPK fertilizer for the grafted seedlings at the same date gave the lowest level of the soil $\mathrm{pH}$ degree and did not differ significantly in turn from the other treatments.

As for the effect of interaction between the dates of grafting and the organic and bio-fertilizers, it was showed that the lowest level of soil $\mathrm{pH}$ was obtained as a result of adding all the concentrations of organic and bio-fertilizers during the two dates of grafting of seedlings, especially when adding organic fertilizer "Nutrigreen" at a concentration of $6 \mathrm{ml} /$ liter for grafted seedlings in the first date compared to the control of these fertilizers during the first and second grafting dates, which are It gave the highest level of soil $\mathrm{pH}$.

With regard to the effect of the interaction between chemical fertilization (NPK) and organic and bio- fertilizers, it was found that the interaction between NPK fertilizer and organic and bio-fertilizers had a positive effect in reducing the soil $\mathrm{pH}$ level, especially the treatment of organic fertilizer " Nutrigreen" at a concentration of $6 \mathrm{ml} /$ liter + control of NPK fertilizer, as it had the lowest values compared to the highest values obtained from the treatment of NPK fertilizer + control of organic and bio-fertilizers.

As for the effect of the interaction among the dates of grafting, chemical fertilization (NPK) and organic and bio- fertilizers, it was clear that the treatment of organic fertilizer " Nutrigreen" at a concentration of $6 \mathrm{ml} /$ liter + control of NPK fertilizer for grafted seedlings at the first date recorded the lowest significant level of soil $\mathrm{pH}$, whereas NPK + fertilizer treatment of control of organic and bio-fertilizers for grafted seedlings in the first and second dates gave the highest levels of soil $\mathrm{pH}$ degree. 
Table 4: Effect of date of grafting and chemical, organic and bio-fertilizers on the $\mathrm{pH}$ in the soil of grafted orange seedlings

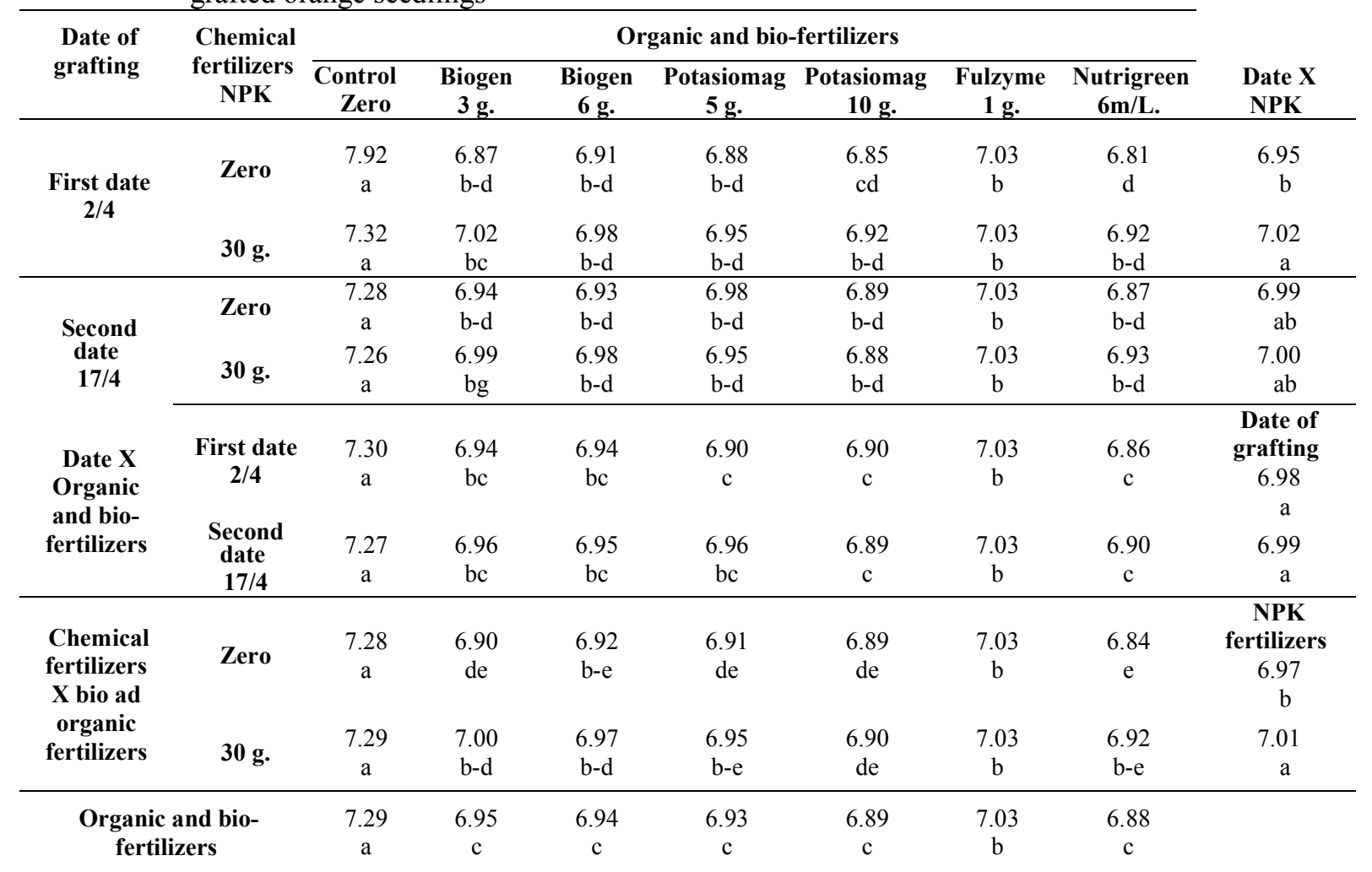

*Mean averages followed by different letters indicate significant differences between them according to Duncan polynomial test at a level of $5 \%$

\section{Discussion}

The effect of chemical fertilizer (NPK) did not have any significant effect on the studied traits, as control treatment was significantly superior to chemical fertilizer treatment (NPK) with a concentration of $30 \mathrm{~g}$ in facilitating nitrogen and phosphorous elements in the soil.

These results obtained in the study may be interpreted as a result of increasing the concentrations used from the chemical fertilizer (NPK) for the seedlings, perhaps this led to a negative effect on the root growth of the seedlings and thus this was later reflected on the characteristics of the vegetative growth of them, as for the increase of nutrients in the soil (Nitrogen, Phosphorus, and Potassium) as a result of adding bio-fertilizers, it may be interpreted as a result of the role of the bio-fertilizer "Biogen" which contains large numbers of nitrogen-fixing bacteria; Azotopacter chroococcum + Azosperillium brasilense, which contribute effectively to providing nutrients in a ready way in the soil, especially nitrogen, which is one of the elements The basic requirements needed by the plant as it constitutes an essential part in the formation of the green pigment for photosynthesis (chlorophyll) in addition to its role in the formation of proteins, amino acids and enzymes (Merwad et al., 2014). As for increasing the soil content of phosphorous, this was explained by the addition of the bio-fertilizer "Fulzyme", which contains a mixture of Bacillus subtilis and Pseudomonas putida, which have a role in the mineralization of organic phosphate compounds through their production of some enzymes such as Protease, Amylase, Chitinase and Lipase and some growth regulators such as oxins and gibberelins provide the plant with its nutritional and water needs and facilitate its absorption by the roots (Kumar et al., 2015), in addition to that the bacteria have a role in transforming the image other than dissolved (triple calcium phosphate) into a soluble form (mono calcium phosphate) as it grows and activates as a result of root secretions and their organic materials and produces the products of nutritional transformations (organic acids such as Formic acid, Fumaric, acetic and Succinic in addition to carbon dioxide) outside of their cells, which leads thus to convert the insoluble triple phosphate into a soft soluble phosphate (García-Fraile et al., 2015) which increases the readiness of 
phosphorous in the soil and facilitates its absorption by the roots of seedlings of origin (Mengel et al., 2001), and the bio-fertilizer "Potasiomag" gave the highest moral value to ready-made potassium in the soil as a result of the role of Bacillus circulans in increasing the soil content of potassium through the secretion of some regulators of Plant growth and thus the development of root system growth and consequently an increased absorption of potassium, as it has the ability to dissolve potassium and make it available to plants in the vicinity of the roots and thus increase the vital effectiveness of absorption (Parmar and Sindhu, 2013).

The addition of organic and organic fertilizers was important in reducing the degree of $\mathrm{pH}$ of the soil and a significant difference from the treatment of control. This may be attributed to the importance of liquid organic fertilizer "Nutrigreen" which contains organic matter, which is of great importance in improving the physical and biological properties of the soil and increasing the mutual catalytic capacity as well as reducing $\mathrm{pH}$ soil, which leads to an increase in the facilitation of major and minor nutrients, and consequently, it reflects positively on plant growth. Also, the decomposition of the organic matter in the organic fertilizer results in many organic acids, especially (Fulvic acid and Humic acid) as well as carbon dioxide, which dissolves in the ground solution, forming carbonic acid, which once formed, it will ionize the bicarbonate and hydrogen ions in the ground solution, thereby reducing the degree of soil interaction (Barakat et al., 2012).

\section{References}

Barakat, M. R., T.A. Yehia and B.M. Sayed, 2012. Response of Newhall Naval Orange to bio-organic Fertilization under Newly Reclaimed Area Conditions I: Vegetative Growth and Nutritional Status. Journal of Horticultural Science \& Ornamental Plants, 4(1):18-25.

Bremner, J.M. and C.S. Mulvaney, 1982. Nitrogen total (595-624).In. A. L. Page (ed.) Methods of soil analysis, Agron. No.9 Part2. Chemical and microbiological properties $2^{\text {nd }}$ ed., Am. Soc. Agron. Madison, WI, USA.

Chaudhary, M., 2000. Fruit crop. In MN Malik (Ed), Horticulture. Biotech Books, Delhi (India), 442443.

Duncan, D. B., 1955. "Multiple range and multiple F tests". Biometrics. 11: 1-42.

García-Fraile, P.; E. Menéndez and R. Rivas 2015. Role of bacterial biofertilizers in agriculture and forestry. AIMS Bioengineering, 2(3):183-205.

Hartmann, H., D. Kester, F. Davies and R. Geneve, 2011. Plant propagation: principles and practices $\left(8^{\text {th }}\right.$ edn.). New York: Prentice Hall.

Hassan, H.S., A. Laila, F. Hagag, M. Abou Rawash, H. El-Wakeel and A. Abdel-Galel, 2010. Response of Klamata Olive young trees to mineral, organic Nitrogen fertilization and some other treatments. Nature and Science, 8(11): $59-65$.

Jackson, M.L., 1958. Soil chemical analysis. Prentis - Hall Inc. Englewood, Cliffs, N. J.

Kumar, A., I. Bahadur, B. Maurya, R. Raghuwanshi, V. Meena, D. Singh and J. Dixit, 2015. Does a plant growth promoting rhizobacteria enhance agricultural sustainability? J Pur Appl Microbiol., 9(1):715-724.

Liu, Y., H. Emily and S.A. Tanumihardjo, 2010. History, Global Distribution, and Nutritional Importance of Citrus Fruits .Comprehensive Review in Food Science and Food Safety, 11:530545.

Mengel, K.E., A. Kirkby, H. Kosegarten and T. Appel, 2001. Principles of plant nutrition. $5^{\text {th }}$ edition. Kluwer Academic Publishers, Dordrecht.

Merwad, M.M., M.S. El-Shamma, A.E. Mansour and M.E. Helal, 2014. The Effect of Nitrogen fertilizer and mycorrhizal fungi on productivity of Citrus trees grown in newly reclaimed soil. Middle East Journal of Agriculture Research, 3(3): 653-662.

Page, A.L., R.H. Miller and D.R. Keeny, 1982. Methods of soil analysis part (2) $2^{\text {nd }}$ (ed). Agronomy 9. Amer. Soc. Agron. Madison Wisconsin.

Parmar, P. and S. Sindhu 2013. Potassium solubilisation by rhizosphere bacteria: Influence of nutritional and environmental conditions. Journal of Microbiology Research, 3(1): 25-31. 
SAS., 2001. SAS/ STAT Users Guide for personal computers, SAS Institute Inc, Cary, N. C. USA.

Shaimaa, A.M. and O.N. Massoud (2017). Impact of Inoculation with Mycorrhiza and Azotobacter under Different N and P Rates on Growth, Nutrient status, Yield and Some Soil Characteristics of Washington Navel Orange Trees . Middle East Journal of Agriculture Research. 6 (3) : 617638 .

Scialabba, N.E., 2002. Organic agriculture, environmental and food security FAO-Rome. 